\title{
STRATEGI PENGELOLAAN DESTINASI PARIWISATA BERBASIS KOMUNITAS PASCA PANDEMI COVID19
}

\author{
Suharsono $^{1}$, A.Y. Agung Nugroho' ${ }^{2}$ Alfonso Harrison ${ }^{3}$ \\ ${ }^{1}$ Prodi Pariwisata, Fiabikom, Unika Atma Jaya jakarta \\ Surel: suharsono@atmajaya.ac.id \\ ${ }^{2}$ Prodi Magister Administrasi Bisnis, Fiabikom, Unika Atma Jaya Jakarta \\ Surel: agungnugraha@atmajaya.ac.id \\ ${ }^{3}$ Prodi Ilmu Komuikasi, Fiabikom. Unika Atma Jaya Jakarta \\ Surel: Alfonso.harrison@atmajaya.ac.id
}

\begin{abstract}
The COVID-19 pandemic has had a significant impact on people's lives today. One of the sectors most affected is the tourism and hospitality sector and its supporting businesses. With the exploitation of natural resources on a large scale, environmental pollution occurs everywhere, concern for nature and the environment decreases. Therefore, there needs to be a fundamental change in the mindset and behavior related to the tourism industry. This paper attempts to reflect on the situation mentioned above regarding decent tourism activities to respond to the pandemic. According to many studies, conventional tourism (mass tourism) contributes to environmental damage to some degree. Therefore, it is time to redesign the post-pandemic tourism destination strategy that considers the concept of Sustainable Tourism, Community Based Tourism (CBT), Social Capital, and the use of Information and Communication Technology (ICT).This study aims to answer how to find an adequate tourism destination management strategy. We examine various options for Community-Based Tourism Destination Management Strategies in the post-Covid 19 pandemic. This paper is a theoretical review of the literature and the results and case studies of previous studies. The results of this study may be able to contribute to more in-depth analysis in future research.
\end{abstract}

Keywords: Sustainable Tourism; Community Based Tourism Destination Management (CBT) Strategy Post Covid19 Pandemic.

\begin{abstract}
ABSTRAK
Pandemi Covid-19 mempunyai pengaruh yang signifikan dalam kehidupan masyarakat saat ini. Salah satu sector yang paling terdampak adalah bidang pariwisata dan perhotelan serta bisnis pendukungnya. Dengan eksploitasi sumber daya alam secara besar-besaran, pencemaran lingkungan terjadi di mana-mana, kepedulian terhadap alam dan lingkungan berkurang. Oleh karena itu, perlu ada perubahan mendasar dalam pola pikir dan perilaku terkait industri pariwisata. Tulisan ini berusaha merefleksikan situasi tersebut di atas terkait dengan kegiatan pariwisata yang layak untuk merespon situasi pandemi. Menurut banyak penelitian, pariwisata konvensional (pariwisata massal) berkontribusi terhadap kerusakan lingkungan sampai tingkat tertentu. Oleh karena itu, sudah saatnya merancang kembali strategi destinasi pariwisata pascapandemi yang mempertimbangkan konsep Sustainable Tourism, Community Based Tourism (CBT), Social Capital, dan pemanfaatan Teknologi Informasi dan Komunikasi (TIK). Penelitian ini bertujuan untuk menjawab bagaimana menemukan strategi pengelolaan destinasi pariwisata yang memadai. Kami mengkaji berbagai opsi Strategi Pengelolaan Destinasi Pariwisata Berbasis Masyarakat di masa pasca Pandemi Covid 19. Makalah ini merupakan kajian teoritis kepustakaan dan hasil serta studi kasus dari penelitian-penelitian sebelumnya.Hasil penelitian ini mungkin dapat memberikan kontribusi untuk analisis yang lebih mendalam pada penelitian selanjutnya.
\end{abstract}

Kata Kunci : Pariwisata Berkelanjutan; Strategi Pengelolaan Destinasi Pariwisata Berbasis Komunitas (CBT) Pasca Pandemi Covid 19

\section{PENDAHULUAN}

Kita semua tahu bahwa pandemi Covid-19 yang terpantau di Indonesia sejak kira-kira sejak bulan Maret 2021 melumpuhkan hampir seluruh sendi kehidupan masyarakat dalam berbagai aspek. Kondisi ini tidak hanya terjadi di Indonesia saja tetapi di seluruh dunia mengalami hal yang sama. Dari berbagai informasi baik televise, medsos dan berbagai seminar online salah satu bidang yang paling terdampak adalah sector pariwisata dan seluruh usaha pendukungnya seperti 
penerbangan, hotel, restoran dan pengelolaan destinasi. Sektor-sektor tersebut dapat dikatakan lumpuh sehingga berdampak pada penurunan pendapatan masyarakat.

Masa sebelum pandemi kita semua tahu bahwa hampir seluruh daerah di Indonesia giat menggalakkan pengembangan destinasi pariwisata. Berbagai potensi yang ada di daerah didorong untuk digali menjadi aktivitas pariwisata. Aktivitas pariwisata diyakini mampu menggerakkan roda ekonomi. Aktivitas pariwisata pada dasarnya bukan aktivitas yang berdiri sendiri tetapi terkait dengan aktivitas pendukung lainnya. Aktivitas pariwisata memiliki dampak "multiplyer" bagi aktivitas ekonomi yang lainnya. Gambaran tersebut pada dasarnya seperti yang diungkapkan Spillane (1989:52) bahwa “.... dapat disimpulkan bahwa pengembangan pariwisata merangsang tumbuhnya usaha-usaha ekonomi tertentu yang saling merangkai dan saling menunjang....”. Sehingga seperti dikatakan oleh Prof. Soebroto dalam sambutan pembukaan acara Konferensi Kemiskinan dan Pemberdayaan Indonesia IPEC (Indonesia Poverty Empowerment Conference) yang berlangsung pada tanggal 14-17 Nopember 2014 di desa Munduk, Bali, (Suharsono, 2014) sebagai berikut :

"Pariwisata khususnya di bali pada dasarnya merupakan 'engine of growth' (pendorong ekonomi) yang tidak perlu diragukan lagi. Oleh karena itu pengembangan pariwisata di Bali sebagai salah satu model terbaik dan nyata tidak boleh menimbulkan kesenjangan yang mengakibatkan kemiskinan khususnya di Bali".

Pendapat di atas pada dasarnya menggambarkan bahwa pengembangan pariwisata yang dikelola dengan baik (tidak hanya di Bali) namun di seluruh wilayah Indonesia mampu memberikan dampak pada pertumbuhan ekonomi. Dengan demikian mampu menjadi sumber pendapatan baik bagi masyarakat, komunitas dan pemerintah. Oleh karena itu jika kita perhatikan khususnya masa sebelum pandemi covid 19 banyak daerah (kabupaten atau provinsi) di Indonesia yang berupaya menggali berbagai potensi yang ada untuk dikelola menjadi destinasi pariwisata. Selain itu juga berupaya meningkatkan aktivitas peningkatan produk pendukungnya seperti akomodasi, kebutruhan oleh-oleh lokal, akses jalan dan sebagainya dengan tujuan untuk menarik para pengunjung datang ke daerahnya. Dengan demikian akan terjadi perkembangan atau perputaran aktivitas ekonomi yang berdampak pada peningkatan pendapatan baik masyarakat, komunitas dan pemerintah.

Namun demikian ketika terjadi pandemi covid 19 hampir semua aktivitas tersebut di atas tidak berjalan. Angka penularan covid 19 di Indonesia termasuk dalam kategori tinggi dan cukup lama. Untuk mengurangi laju penularan covid 19 pemerintah telah melakukan berbagai upaya agar masyarakat atau bangsa Indonesia dapat terselamatkan dari bahaya covid, mulai dari upaya pembuatan vaksin hingga program vaksinasi. Selain itu juga membuat berbagai pedoman perilaku seperti mulai dari wajib memakai masker, ditabah dengan 3 M (Memakai Maskes, Mencuci, Menjaga jarak), 5 M (Memakai Maskes, Mencuci, Menjaga jarak,Menjauhi Kerumunan dan Mengurangi Mobilitas). Ternyata dengan berbagai pedoman perilaku (sehat) tersebut penyebaran covid 19 masih saja cukup tinggi. Mengingat kondisi geografis Indonesia yang cukup luas dan tingkat penyebaran covid yang berbeda antara daerah satu dengan daerah lainnya maka pemerintah tidak membuat kebijakan "lockdown" seperti yang dilakukan di beberapa negara, tetapi dengan kebijakan pembatasan dengan prinsip seperti orang berkendaraan yaitu perpaduan antara "gas" dan "rem". Dengan kebijakan ini diharapkan tetap terjadi keseimbangan antara pergerakan ekonomi yang juga perlu bagi pemenuhan kebutuhan masyarakat tetapi juga tetap memperhatikan laju penyebaran covid 19. Kebijakan tersebut kemudian dikenal dengan PKM (Pembatasan Kegiatan Masyarakat) dan kemudian dipertegas lagi dengan PPKM (Pemberlakuan Pembatasan Kegiatan Masyarakat). Kebijakan PPKM resmi diberlakukan sejak tanggal 3 Juli - 20 Juli 2021. Awalnya hanya diberlakukan untuk wilayah 
pulau Jawad an Bali. Namun karena tingkat penyebaran semakin meluas maka diperluas ke 15 wilayah lain selain pulau Jawad an Bali (Kompas.com-diunduh pada hari Sabtu, 21 Agustus 2021).

Prakteknya, pelaksanaan kebijakan PPKM di beberapa daerah dilaksanakan berbeda-beda sesuai dengan kondisi daerah masing-masing. Dari berbagai informasi seperti berita di televise, medsos dan seminar (online) dapat diketahui bahwa terkait khususnya dengan kegiatan kepariwisataan hampir semua daerah melakukan penutupan sementara untuk kegiatan pariwisata (destinasi pariwisata). Dampaknya adalah sebagian aktivitas pariwisata terganggu atau bahkan tidak ada aktivitas sama sekali karena tidak diperbolehkan menerima pengunjung. Disisi lain seperti telah dijelaskan di atas bahwa pengembangan dan pengelolaan pariwisata yang baik merupakan salah satu sumber pendapatan baik bagi pemerintah maupun bagi masyarakat. Secara tidak langsung masa pandemi ini mengajak kita untuk melakukan berbagai perubahan dalam perilaku berwisata. Semula orang berwisata cenderung dalam bentuk kelompok banyak sekarang berubah dalam kelompok kecil (komunitas) bahkan hanya pada level keluarga. Semula cenderung berperilaku bebas sekarang harus menyesuaikan dengan protokol kesehatan, termasuk kebersihan lingkungan. Situasi seperti ini pada dasarnya mengajak kita untuk lebih peduli pada aspek lingkungan (ekowisata) yang pada akhirnya mengarah pada wisata berkelanjutan (sustainable tourism). Selain itu dapat dikatakan juga bahwa masa pandemi ini pada dasarnya mengajak kita untuk lebih memperhatikan berbagai potensi lokal yang dapat dikembangkan menjadi produk pendukung pariwisata. Dengan demikian maka aktivitas pariwisata mampu menjadi penggerak aktivitas ekonomi masyarakat. Aktivitas pariwisata harus bangkit kembali sehingga mampu menunjukkan fungsinya kembali sebagai penggerak perekonomian masyarakat. Disinilah pentingnya mencari strategi yang tepat dalam pengelolaan destinasi pariwisata pada masa pasca pandemi covid 19

\section{Rumusan Masalah}

Berdasarkan uraian di atas maka yang menjadi fokus atau permasalahan dalam tulisan ini adalah : "Strategi apa saja yang dapat diterapkan dalam pengelolaan destinasi pariwisata berbasis komunitas pasca pandemi covid 19 ?".

Untuk menjawab permasalahan di atas maka dalam tulisan ini dikaji secara teortis kepustakaan tentang berbagai strategi dalam mengelola destinasi pariwisata berbasis komunitas. Selain itu juga dibahas tentang Pariwisata Berkelanjutan, Pengembangan Pariwisata Berbasis Komunitas dan Modal Sosial, Peran Pariwisata dalam Peningkatan Ekonomi Masyarakat.

\section{METODE PENELITIAN}

Gagasan pemikiran dalam tulisan ini pada dasarnya merupakan kajian literatur (teoritis kepustakaan) dan didukung dengan beberapa contoh dari hasil penelitian lapangan sebelumnya di beberapa destinasi pariwisata seperti di pulau Untung Jawa, Biboki Kefamenanu NTT dan kabupaten Pringsewu Lampung. Selain itu juga diperdalam dengan hasil observasi, diskusi, seminar online terkait dengan situasi pandemi yang dianggap menjadi penyebab terjadinya hambatan dari berbagai aspek kehidupan masyarakat.

\section{HASIL DAN PEMBAHASAN}

Sub bab ini pada dasarnya membahas tentang berbagai strategi pengelolaan destinasi pariwisata berbasis komunitas pasca pandemi covid 19. Selain itu juga membahas tentang konsep-konsep yang terkait dengan pengembangan pariwisata berbasis komunitas, destinasi pariwisata berkelanjutan dan peran pariwisata dalam peningkatan ekonomi masyarakat. 


\section{Pengembangan Pariwisata Berkelanjutan}

Pembahasan konsep pariwisata pada dasaarnya sangat terkait dengan konsep wisata. Keduanya saling terkait tetapi maknanya berbeda. Berdasarkan Undang-undang No. 10 tahun 2009 tentang kepariwisataan disebutkan bahwa :

"Wisata adalah kegiatan perjalanan yang dilakukan oleh seseorang atau sekelompok orang dengan mengunjungi tempat tertentu untuk tujuan rekreasi, pengembangan pribadi, atau mempelajari keunikan daya tarik wisata yang dikunjungi dalam jangka waktu sementara."

Sedangkan pariwisata adalah : “...berbagai macam kegiatan wisata dan didukung berbagai fasilitas serta layanan yang disediakan oleh masyarakat, pengusaha, Pemerintah, dan Pemerintah Daerah."

Pengertian tersebut di atas pada dasarnya menggambaran bahwa konsep wisata lebih menekankan pada aspek mobilitas secara fisik (melakukan perjalaanan) sedangkan konsep pariwisata lebih fokus pada berbagaiaktivitas yang terkait dengana wisata yang didukung dengan berbagai fasilitas dan layanan. Dengan demikian menjadi semakin jelas meskipun secara awam masih sering diartikan sama. Wisata lebih fokus pada orang/wisatawan yang berkunjung sedangkan pariwisata lebih kompleks lagi yaitu seluruh aktivitas terkait wisata dengan penyediaan berbagai fasilitas dan layanan pendukung lainnya seperti, penyedia berbagai oleholeh, atraksi, akomodasi dan keperluan lain..

Pada masa pandemi karena hampir di seluruh dunia melakukan kebijakan pembatasan pergerakan manusia baik antar negara maupun antar wilayah maka aktivitas kepariwisataan dapat dikatakan lumpuh. Sebagai salah satu upaya agar aktivitas pariwisata tetap berjalan maka muncul konsep "pariwisata virtual” (virtual tourism). Dari beberapa pendapat yang disimak dari seminar online dapat disimpulkan bahwa pemahaman konsep pariwisata virtual masih menjadi pro dan kontra. Menurut hemat kami pemahaman tentang pariwisata virtual masih membutuhkan diskusi dan kajian yang panjang dan lebih serius. Dari bererapa literatur yang digunakan dalam tulisan ini misalnya Marsono $(2019,2)$ pada dasarnya berpandangan bahwa konsep wisata lebih fokus pada aspek perjalanan manusia (fisik). Tulisan ini tidak bermaksud memperdebatkan konsep tersebut. Untuk memperjelas arah kajian maka dalam tulisan ini mengikuti pemahaman wisata yang terkait dengan perjalanan manusia baik perorangan maupun kelompok. Bahwa dalam masa pandemi ini mau tidak mau harus dilaakukan berbagai perubahan khususnya dalam hal pelayanan jasa pariwisata yang didukung dengan teknologi informasi dan komunikasi, akan dibahas tersendiri dalam sub bab strategi yang perlu dikembangkan dalam pengelolaan destinasi pariwisata pasca pandemi.

Aktivitas pariwisata jika tidak dikelola dengan baik dapat menyebabkan berbagai dampak negatif. Seperti dikatakan oleh Spillance (1989, 139-141) bahwa aktivitas pariwisata padamdasarnya juga dapat menyebabkan beberapa dampak negative antara lain (1) pariwisata dapat merusak lingkungan, (2) pariwisata ditangan orang asing, (3) berubahnya tujuan kesenian dan upacara tradisional, (4) lingkungan yang kurang terjaga, (5) meningkatnya pencurian benda-benda kuno. Selanjutnya Sunaryo (2013: 69) menjelaskan bahwa aktivitas pariwisata dapat berdampak negatif dengan tesis seperti pada bagan di bawah : 


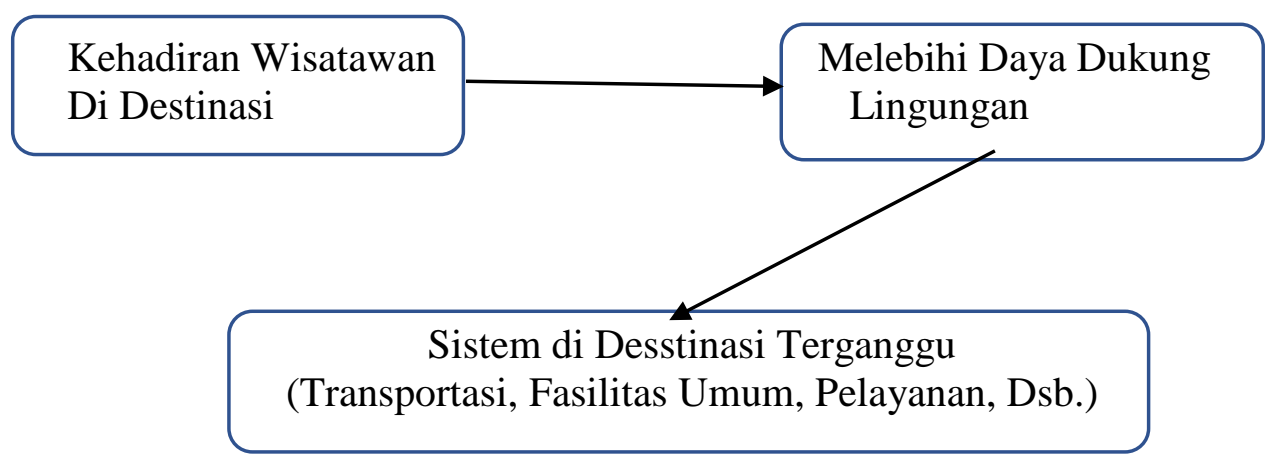

Sumber : Disalin dari Sunaryo (2013:69)

Pendapat dan tesis di atas pada dasarnya menggambarkan bahwa pengelolaan destinasi pariwisata harus lebih berorientsi ke masa depan atau berkelanjutan. Masa pandemi disatu sisi terkesan seolah-olah menjadi penyebab berbagai kendala aktivitas terutama ekonomi tetapi dilain pihak sebenarnya dapat dimaknai bahwa perlu ada perubahan perilaku yang selama ini barangkali sudah melampaui batas-batas kewajaran. Dalam kontek kegiatan pariwisata misalnya telah terjadi berbagai dampak negatif yang justru dapat berakibat lebih fatal. Oleh karena itu sekarang saatnya untuk mengubah perilaku dalam berwisata. Jika sebelumnya kurang memperhatikan aspek lingkungan maka sekarang harus mulai peduli pada lingkungan. Kelestarian alam merupakan bagian tak terpisahkan dari kehidupan manusia. Seperti juga dikatakan oleh Siswono (2019, 125-126) bahwa pada dasarnya seluruh unsur yang dibutuhkan dalam kehidupan manusia diambil dari lingungan. Selanjutnya dikatakan bahwa "...semakin tinggi tingkat kebudayaan makin beraneka ragam kebutuhan hidupnya..". Pada jaman modern sekarang ini yang salah satunya ditandai dengan semakin meningkatnya kegiatan industri yang seolah-olah menjadi kebutuhan manusia maka semakin tinggi pula aktivitas pengambilan berbagai potensi alam untuk memenuhi kebutuhan industri. Meskipun terkesan saling menghindar siapa yang seharusnya bertanggungjawab tetapi harus diakui bahwa aktivitas industri yang tinggi menjadi salah satu penyebab terjadinya berbagai bencana alam seperti banjir, kebakaran hutan, pemanasan global, perubahan cuaca ekstrim dan sebagainya. Hal senada dikatakan oleh Siswono $(2019,126)$ bahwa "eksploitasi sumber daya alam semakin meningkat untuk memenuhi bahan dasar industri. Sebaliknya, hasil industry berupa asap dan limbah mulai menurunkan kualitas lingkungan. Sekaranga bagaimana ?, kehidupan manusia sepanjang masih dikehendaki oleh Tuhan maka harus tetap berlangsung terus. Manusia dan alam merupakan suatu ekosistem yang saling membutuhkan. Seluruh kebutuhan unsur kehidupan manusia dipenuhi dari alam. Oleh karena itu saatnya untuk mengubah pandangan dan perilaku eksploitasi yang berlebihan harus diubah bahwa alam adalah "sahabat kita", oleh karena itu harus dijaga, dikendalikan dan dilestarikan. Tidak cukup hanya dalam bentuk slogan baik yang dipasang di spanduk, baliho dan seminar-seminar saja tetapi harus betul-betul menjadi sebuah gerakan perilaku yang peduli lingkungan. Sering terlihat dalam suatu kawasan terpasang baliho besar bertuliskan dengan tema "hijau", "go green" tetapi pohon-pohon disekitarnya malah ditebangi. Demikian juga aktivitas pariwisata yang harus diakui juga sebagai salam satu penyebab terjadinya kerusakan alam harus berubah menjadi pariwisata yang peduli pada lingkungan alam. Oleh karena itu kajian tentang konsep ekowoisata perlu ditingkatkan dan diperdalam antara lain melalui penelitian-penelitian yang lebih serius.

Demikian juga dalam Undang-undang No.10 Tahun 2009 pasal 2 bagian huruf "h" pada dasarnya diamanatkan bahwa asas penyelenggaraan pariwisata di Indonesia adalah 
berkelanjutan. Disinilah pentingnya pengembangan destinasi pariwisata yang berorientasi apada aspek berkelanjutan.

Menurut Daryanto dan Suprihatin (2013:32) dikatakan bahwa secara umum kerusakan lingkungan terjadi karena faktor alamiah dan perilaku atau aktivitas manusia. Harus diakui bahwa aktivitas pariwisata menjadi salah satu penyumbang terjadinya kerusakan lingkungan. Berdasarkan pengamatan, di beberapa tempat pariwisata masih sering terlihat tumpukan sampah yang kurang tertangani dengan baik. Hal ini terjadi karena biasanya pemngunjung dalam bentuk rombongan membawa bekal sendiri dan dimakan di destinasi. Selain itu juga masih sering terlihat pengunjung yang membawa makanan kecil (camilan) dan tidak membuang bungkus pada tempatnya. Demikian juga dikatakan oleh Keraf (2010:1) bahwa pada dasarnya berbagai kasus kerusakan lingkungan hidup hamper di seluruh dunia termasuk di Indonesia terutama disebabkan oleh perilaku manusia yang tidak bertanggung jawab. Secara umum oleh Edward Inskeep, Burnet dan Salm yang dikutip oleh Sunaryo (2013: 73-74) dikatakan bahwa perusakan lingkungan antara lain meliputi : (1) Pencemaran air tanah, (2) Pencemaran udara, (3) Kebisingan udara, (4) Polusi pemandangan, (5) Persoalan sampah, (6) Kerusakan lingkungan, (7) Bencana lingkungan, (8) Kerusakan situs dan peninggalan sejarah dan (9) Perosoalan tata guna tanah. Menurut Nugroho $(2019,15)$, dikatakan sebagai berikut "ekowisata adalah sebagian dari sustainable touris". Berdasarkan pendapat tersebut dapat dikatakan bahwa ekowisata merupakan salah satu wujud implementasi dari pariwisata berkelanjutan. Selanjutnya dikatakan bahwa :

"ekowisata adalah perjalanan wisata ke wilayah-wilayah yang lingkungan alamnya masih asli, dengan menghargai warisan budaya dan alamnya, mendukung upaya-upoaya konservasi, tidak menghasilkan dampak negative dan memberikan keuntungan sosial ekonomi serta menghargai partisipasi penduduk lokal"

Di atas telah dijelaskan bahwa pandemic covid 19 pada dasarnya mengajak kita untuk berperilaku lebih bijak. Dalam konteks pariwisata maka perlu meningkatkan kepedulian pada lingkungan alam sekitar dengan tindakan nyata. Salah satu contoh terkait dengan tindakan nyata peduli lingkungan misalnya ketika kami berkunjung ke Danau Tiga Warna Kelimutu di Mangarai Flores Barat terlihat beberapa pemuda dengan menenteng karung goni sedang memungut berbagai sampah plastik. Demikian juga salah satu kegiatan pemuda Karang Taruna di pulau Untung Jawa Kepulauan Seribu melakukan kegiatan mengumpulkan sampah kemudian dirangkai menjadi jala (jarring) dan digunakan untuk pagar lapangan olah raga.

Terkait dengan peran serta antar pemangku kepentyingan dalam pengelolaan pariwisata, Sunaryo (2013: 77) berpendapat bahwa :

"Prinsip dari penyelenggaraan tata kelola kepariwisataan yang baik ini pada intinya adalah adanya koordinasi dan sinkronisasi program antar pemangku kepentingan yang ada serta pelibatan partisipasi aktif yang sinergis (terpadu dan saling menguatkan) antara fihak pemerintah, swasta/industri pariwisata, dan masyarakat setempat yang terkait”.

Pendapat di atas menggambarkan pentingnya kerjasama antar pemangku kepentingan untuk menjaga keberlangsungan suatu destinasi sehingga semua ikut merasakan hasilnya.Dengan demikian dapat dikatakan bahwa pengembangan destinasi dan kepariwisataan ke depan (pasca pandemi) harus mengajak semua pemangku kepentingan untuk memperhatikan, merawat dan melestarikan lingkungan untuk menjamin agar aktivitas pariwisata tetap berjalan, dan semakin berkualitas.

Masa pandemi sebenarnya juga mengajak kita semua untuk memikirkan dan menerapkan kembali tentang "gotong royong". Gotong royong sebenarnya merupakan salah satu ciri sistem 
interaksi masyarakat kita yang sekarang sudah semakin kurang diperhatikan. Sekarang saatnya untuk kembali saling berperan, saling membantu, saling menjaga dan sebagainya. Sebagai contoh ketika salah satu warga disekitar kita ada yang terkena/terpapar covid 19 dan menjalani isolasi mandiri maka dengan berbagai upaya seluruh warga lainnya ikut berupaya membantu memenuhi kebutuhan keluarga tersebut. Demikian juga dalam konteks pengelolaan destinasi pariwisata maka selain para pemangku kepentingan juga para wisatawan harus mulai dilibatkan untuk secara bersama-sama bertanggungjawab atas destinasi yang dikunjunginya.

\section{Pengembangan Destinasi Pariwisata Berbasis Komunitas dan Modal Sosial}

Di atas telah dijelaskan bahwa pandemi covid 19 seolah-olah membatasi seluruh aktivitas manusia. Sebagai contoh dengan adanya kebijakan lockdown di beberapa negara maka seluruh aktivitas masyarakat dibatasi secara ketat. Namun demikian disisi lain sebenarnya mengajak kita untuk berfikir ulang tentang apa yang kita lakukan selama ini. Jangan-jangan ada yang perlu dibenahi sehingga kedepan justru akan menjadi lebih baik lagi. Sebagai contoh dalam pengembangan destinasi pariwisata selama ini yang cenderung memanfaatkan potensi secara berlebihan maka tidak jarang di beberapa destinasi justru menimbulkan dampak negatif. Demikian juga dengan model pengelolaan yang cenderung mengarah pada kunjungan wisatawan dalam jumlah besar maka dapat berakibat pada ketidakmampuan daya dukung dalam menyediakan berbagai fasilitas yang pada akhirnya berdampak pada berbagai masalah seperti, sampah, kepadatan transportasi, dan masalah-masalah sosial dan budaya.

Jika kita refleksikan tentang pandemi covid 19 ini maka akan ketemu sebuah logika berfikir dan berperilaku baru yang kemudian disebut dengan "era baru". Intinya kita harus mau berubah. Dalam tataran perilaku maka kita harus bersedia mengubah pola perilaku yang selama ini barangkali sudah tidak sesuai dengan sisten tatanan alam semesta yang telah dianugerahkan kepada kita. Sebagai contoh sederhana misalanya, alam semesta telah menyediakan berbagai kebutuhan seperti hutan dan segala isinya, sungai dan segala isinya yang sangat cukup untuk memenuhi kebutuhan hidup manusia. Namun karena keinginan untuk mencapai keuntungan yang lebih besar maka berbagai sumber daya di atas dimanfaatkan secara berlebihan maka pada akhirnya justru menimbulkan berbagai bencana seperti banjir, perubahan cuaca ektrim, kekeringan, gagal panen, serangan berbagai hama pada lahan pertanian masyarakat dan sebagainya.

Demikian juga dalam model pengembangan destinasi pariwisata yang cenderung berorientasi pada pertumbuhan untuk memperoleh keuntungan yang besar maka cenderung melibatkan para pemodal besar yang disebut dengan "investor" untuk mengelola suatu kawasan destinasi pariwisata. Damanik (editor, 2021, 55) menggaambarkan situasi tersebut sebagai berikut “ ..sebagaimana di negara berkembang laiinya, struktur kepemilikan industry pariwisata di Indonesia juga ditandai oleh monopoli capital asing, khususnya pada segmen hotel berbintang....". Pendapat tersebut menggambarkan bahwa masih begitu kuatnya penetrasi modal asing dalam pengelolaan aktivitas pariwisata khususnya pada aspek akomodasi (hotel berbintang). Selanjutnya dikatakan sebagai berikut “..tidak hanya hotel-hotel kelas atas, pasar hotel kelas menengah bahkan bawahpun sudah dimasuki oleh modal asing..". Hal ini menggambarkan meskipun secara teoritis pengembangan kajian konsep atau teori tentang pariwisata seperti "pemberdayaan", "ekowisata", "pariwisata berbasis komunitas" dan sebagainya yang diharapkan mampu merubah struktur perekonomian masyarakat (lokal) tampak belum efektif.

Oleh karena itu terdapat pandangan bahwa pengelolaan destinasi pariwisata di beberapa tempat cenderung kurang memperhatikan aspek keterlibatan masyarakat setempat (lokal) untuk ikut menikmati hasil potensi daerahnya. Disinilah (sekarang) pentingnya untuk mengkaji kembali model pengembangan destinasi pariwisata ke depan yang lebih memperhatikan pada partisipasi 
masyarakat lokal. Sebenarnya Undang-undang No. 10 tahun 2009) Pasal 5 poin "e" telah mengamanatkan kepada kita semua khususnya para pemangku kepentingan bahwa dalam melaksanakan pengembangan destinasi pariwisata di Indonesia harus memegang prinsip untuk “memberdayakan masyarakat setempat". Demikian juga Spillane (1989:55), Sunaryo (2013: 50) pada dasarnya menyatakan bahwa pengembangan destinasi pariwisata harus melibatkan masyarakat lokal. Dalam konteks ini Spillane memberi penekanan pada pentingnya aspek psikologis mastyarakat " ... pada penduduk setempat harus dibangkitkan perasaan, bahwa mereka mempunyai kepentingan terhadap keberhasilan daerah pariwisata yang bersangkutan." Pendapai tersebut pada dasarnya menggambarkan begitu pentingnya melibatkan masyarakat karena secara sosiologis dan psikologis merekalah yang lebih tahu tentang kondisi, situasi dan karakter lingkungannya. Dengan demikian ke depan masyarakat tidak hanya sekedar menjadi penonton atas keberhasilan daerahnya dalam pengembangan destinasi priwisata tetapi juga ikut menikmati keberhasilan tersebut. Dengan kata lain masyarakat harus menjadi pelaku utama dalam pengelolaan destinasi pariwisata. Untuk itu maka diperlukan kajian/penelitian lebih lanjut dan mendalam baik untuk mempersiapkan masyarakat terutama di daerah pengembangan destinasi baru maupun pengembangan konsep-konsep seperti : "modal sosial", "CBT" yang lebih berpihak pada kepentingan masyarakat (lokal)

Pengembangan dan pengelolaan destinasi pariwisata yang berorientasi pada partisipasi sebagai upaya untuk pemberdayaan masyarakat (lokal) pada dasarnya merupakan konsep "Community Based Tourism Development" disngkat dengan "CBT" (Sunaryo (2013:138). Selanjutnya dikatakan oleh Hausler yang dikutip Sunaryo (ibid:139) bahwa:
"CBT pada hakekatnya merupakan salah satu pendekatan dalam pengembangan pariwisata yang menekankan pada masyarakat lokal, baik yang terlibat langsung dalam industri pariwisata maupun tidak, dalam bentuk pemberian akses pada manajemen dan sistem pembangunan kepariwisataan yang berujung pada pemberdayaan politis melalui kehidupan yang lebih demokratis, termasuk dalam pembagian keuntungan dari kegiatan kepariwisataan secara lebih adil bagi masyarakat lokal.

Pengertian di atas pada dasarnya menggambarkan bahwa pengelolaan destinasi pariwisata dengan model CBT tidak sekedar mampu memberikan keuntungan (secara ekonomi) tetapi juga penting diperhatikan bahwa mereka secara politik juga ikut dilibatkan. Apa artinya ? mereka juga ikut dilibatkan dalam berbagai proses pengambilan keputusan terkait dengan pengembangan destinasi pariwisata di daerahnya. Pendapat di atas dapat juga bermakna bahwa para pemangku kepentingan diajak untuk merubah pola pikir bahwa masyarakat setempat jauh lebih mengetahu tentang berbagai kondisi dan situasi dan karakter daerahnya. Lebih tegas lagi dikatakan oleh Prasiasa $(2013,87)$ bahwa pada dasarnya pengembangan pariwisata berbasis komunitas (masyarakat) harus melibatkan masyarakat (lokal). Tanpa melibatkan masyarakat maka tujuan dan sasaran tidak akan tercapai.

Selain itu, dengan berbagai pembatasan baik secara global, nasional maupun wilayah (daerah) maka sebenarnya merupakan suatu kesempatan untuk berinovasi dengan mengubah pola kunjungan yang selama ini cenderung dengan model pariwisata masal/kelompok besar (mass tourism), menjadi lebih fokus pada pengembangan kelompok-kelompok kecil (komunitas) dengan jangkauan yang relatif lebih terbatas (lokal). Selain itu juga tetap harus memperhatikan dan mempersiapkan untuk antisipasi perkembangan situasi pariwisata global. Konsep lain yang sangat terkait dengan pengembangan pariwisata berbasis komunitas adalah modal sosial (social capital). Modal sosial ini cenderung tidak terlihat tetapi sangat berpengaruh terhadap keberhasilan pengembangan destinasi pariwisata berbasis komunitas (CBT). Seperti dikatakan oleh Usman $(2018,127)$ bahwa : 
"Kegiatan pemberdayaan ditandai dengan kegiatan-kegiatan peningkatan akses pada informasi, inklusivisme, partisipasi, akuntabilitas dan penguatan kapasitas organisasi lokal. Kegiatan-kegiatan tersebut membutuhkan elemen-elemen yang terdapat dalam modal sosial.....".

Pendapat di atas pada dasarnya menggambarkan keterkaitan antara CBT yang fokus pada pelibatan/partisipasi masyarakat dan modal sosial. Menurut Hasbullah (2006), Field (2018), Usman (2018), konsep modal sosial dikembangkan oleh Bourdieu, Colman, Putnam dan Fukuyama. Selanjutnya Usman $(2018,4)$ menggambarkan bahwa konsep modal sosial sebagai berikut : "Pembahasan tentang modal sosial lazim dikaitkan dengan upaya mengelola, meningkatkan dan mendayagunakan relasi-relasi sosial sebagai sumber daya yang diinvestassikan untuk memperoleh keuntungan ekonomi atau manfat sosial". Sedangkan elemen-elemen tersebut meliputi (a) kepercayaan (trust), (b) arus informasi (jejaring) dan (c) norma-norma.

Uraian di atas pada dasarnya menggambarkan pentingnya konsep CBT dalam pengelolaan destinasi pariwisata didukung dengan konsep modal sosial. Kedua konsep tersebut pada dasarnya lebih menekankan pentingnya melibatkan masyarakat (lokal). Dengan demikian masyarakat lokal dalam pengembangan destinasi pariwisata dapat menjadi pelaku utama. Situasi pasca pandemi memerlukan hubungan yang saling membantu, melengkapi dan saling mendukung. Oleh karena itu penerapan konsep CBT dan Modal Sosial dan didukung dengan pemanfaatan ICT dalam pengelolaan destinasi pariwisata merupakan suatu kebutuhan pada masa pasca pandemi sekarang ini.

\section{Strategi Pengelolaan Destinasi Pariwisata Pasca Pandemi}

Di atas telah dijelaskan bahwa pandemi covid 19 dalam konteks pengelolaan destinasi priwisata harus dimaknai sebagai upaya untuk melakukan berbagai perubahan perilaku. Dengan memperhatikan konsep-konsep yang telah diuraikan di atas seperti pariwisata berkelanjutan, ekowiosata, pariwisata berbasis komunitas (Community Base Torism-CBT), dan Modal Sosial serta pariwisata yang bertanggungjawab (Risponsible Tourism) maka beberapa startegi yang perlu diperhatikan dalam pengelolaan destinasi pariwisata meliputi antara lain :

\section{Inovasi yang kreatif}

Secara umum inovasi dapat dipahami sebagai perubahan baik cara pandang maupun perilaku untuk melakukan penemuan baru sebagai respon terhadap perubahan situasi.

Situasi kehidupan masyarakat moderen antara lain ditandai dengan semakin tingginya aktivitas untuk memenuhi kebutuhan hidup. Hal ini terutama terjadi di daerah perkotaan atau kota-kota besar. Rutinitas pekerjaan yang sangat tinggi sehingga sering menimbulkan perasaan bosan. Pada masa sebelum pandemi terlihat begitu tingginya warga perkotaan yang memanfaatkan waktu libur untuk pergi ke luar kota (berlibur-rekreasi). Sebagai contoh setiap akhir pekan maka destinasi di sekitar Jabodetabek ramai dikunjungi sehingga menimbulkan kemacetan di beberapa daerah seperti kawasan Puncak Bogor, Anyer (Banten). Demikian juga pada saat pandemi meskipun diberlakukan berbagai pembatasan tetapi begitu ada kesempatan terlihat beberapa tempat banyak dikunjungi wisatawan. Contoh di atas pada dasarnya menggambarkan bahwa berwisata sudah menjadi kebutuhan terutama bagi masyarakat perkotaan. Dalam konteks ini Suyitno (2001:2) mengatakan bahwa “... maka tidak berlebihan kiranya bila dikatakan bahwa wisata telah menjadi salah satu tumpuan harapan manusia modern untuk memenuhi salah satu kebutuhannya."

Dari beberapa sumber yang dipergunakan dalam tulisan ini seperti Mulyadi (2009:8) mengatakan bahwa "unsur pembentuk pengalaman wisatawan yang utama adalah adanya daya tarik dari 
suatu tempat atau lokasi". Pendapat di atas pada dasarnya menggabarkan bahwa faktor penting yang mendorong wisatawan berkunjung adalah adanya daya tarik yang khas dari suatu destinasi. Kekhasan inilah yang pada akhirnya membentuk pengalaman unik bagi wisatawan yang berkunjung. Bahasa lain yang sering dipakai adalah pengalaman yang "sensasional". Disinilah pentingnya menciptakan inovasi baru yang khas baik destinasi maupun produk pendukungnya.

Selain itu menurut Damanik dan Weber (2006:11) harus memperhatikan konsep "3A". yaitu (1) Atraksi, (2) Aksesibilitas, (3) Amenitas. Atraksi pada dasrnya merupakan obyek wista itu sendiri yang dapat memberikan rasa kenikmatan, kepuasan dan pengalaman yang khas (unik) bagi wisatawan. Aksesibilitas pada dasarnya merupakan seluruh infrastruktur transportasi yang memudahkan wisatawan untuk mengunjungi suatu destinasi baik pada saat datang maupun pulang. Sedangkan Amenitas pada dasarnya merupakan infrastruktur yang sebenarnya tidak langsung terkait tetapi memberikan kemudahan bagi wisatawan. Dapat dikatakan bahwa amenitas pada dasarnya merupakan sarana pelengkap yang dibutuhkan wisatawan ketika berkunjung ke suatu destinasi. Berdasarkan pengamatan dan hasil penelitian terkait dengan upaya peningkatan pengunjung, fasilitas yang sangat dibutuhkan wisatawan adalah "toilet". Selain itu juga produk pendukung yang khas seperti oleh-oleh, produk kerajinan dan sebaginya. Masa pandemi pada dasarnya dapat diambil hikmahnya bahwa ini merupakan suatu kesempatan bagi pengelola destinasi untuk melakukan berbagai pembenahan berbagai sarana dan jasa pendukung lainnya sebagai persiapan menjelang pasca pandemi. Sebagai contoh seperti yang dilakukan pengelola destinasi Talang Indah di kabupaten Pringsewu Lampung, pada saat pandemi pemerintah daerah (Pemda) kabupaten Pringsewu membuat kebijakan untuk menutup sementara seluruh destinasi pariwisata. Namun demikian Pokdarwis sebagai pengelola destinasi tetap melakukan berbagai upaya untuk membenahi berbagai fasilitas yang ada dan tetap menjalin komunikasi baik dengan komunitas, pemerintah (Disporapar-Dinas Kepemudaan Olah Raga dan Pariwisata). Selain itu juga melakukan interaksi dengan berbagai mitra melalui konsep modal sosial (Kepercayaan, jejaring dan nilai).

\section{Penerapan Protokol Kesehatan}

Terkait dengan pengelolaan destinasi pariwisata, pemerintah telah menetapkan kebijakan terkait dengan pencegahan penyebaran covid 19 melalui program CHSE (Clean, Healty, Save, Ecological). Selain itu juga pedoman protocol kesehatan 5M yaitu (1) Memakai Masker, (2) Mencuci (tangan), (3) Menjaga jarak, (4) Menghindari kerumunan dan (5) Mengurangi mobilitas. Penerapan kebijakan dan prokes tersebut sangat penting untuk meyakinkan kepada pengunjung (wisatawan) bahwa destinasi yang dikelola betul-betul aman terutama dari penyebaran covid 19. Oleh karena itu harus disediakan tenaga pendukung untuk terlaksananya penerapan prokes tersebut. Tidak cukup hanya dibuatkan spanduk, atau gambar-gambar tetapi betul-betul harus disedikan sarana pendukungnya seperti tenaga pelaksana, sarana cuci tangan yang memadahi (cukup dan mudah digunakan), pengukur suhu, masker yang bisa dibeli pengunjung yang lupa tidak membawa dan sebaginya. Selain itu juga upaya pembatasan pengunjung sehingga tidak menimbulkan kerumunan yang berlebihan.

\section{Peningkatan Partisipasi Komunitas}

Pendekatan pariwisata berbasis komunitas (CBT) pada dasarnya menuntut adanya partisipasi masyarakat (lokal) dalam aktivitas pariwisata di suatu destinasi. Di beberapa destinasi pariwisata telah dibentuk kelompok masyarakat setempat sebagai pengelola destinasi dengan nama Pokdarwis (Kelompok Sadar Wisata). Pokdarwis sudah memiliki forum komunikasi antar pokdarwis di daerah bahkan sampai tingkat nasional. Pokdarwis pada dasarnya dibentuk dan dilaksanakan oleh orang-orang yang sangat peduli terhadap pengembangan potensi pariwisata di suatu daerah. Mereka bukan ASN (Aparat Sipil Negera) sehingga tidak digaji oleh pemerintah 
tetapi mereka sangat aktif dalam menggerakkan berbagai unsur pendukung kegiatan pariwisata yang ada dalam masyarakat. Dengan peningkatan keterlibatan masyarakat diharapkan dapat tercipta berbagai kegiatan ekonomi yang berbasis pada potensi lokal sehingga dapat meningkatkan nilai tambah hasil produksi masyarakat. Aktivitas tersebut sebenarnya sekaligus menciptakan lapangan kerja baru bagi masyarakat dan khas. Kekhasan produk inilah yang terutama menjadi faktor daya tarik wisatawan untuk berkunjung dan membeli produk tersebut. Sebagai contoh mislanya yang dilakukan oleh Pokdarwis kabupaten Pringsewu. Mereka melakukan berbagai upaya kerjasama dengan masyarakat antara lain untuk memproduksi berbagai hasil tanaman masyarakat untuk dijadikan produk pendukung yang khas. Selain keripik pisang, sekarang sedang digalakkan antara lain produk olahan "minyak klentik" dan gula aren. Minyak klentik dan gula aren ini sudah mulai jarang ditemukan apalagi yang betul-betul asli. Oleh karena itu produk ini diharapkan akan menjadi produk unggulan di kabupaten Pringsewu yang menjadi daya tarik wisatawan. Pelatihan pembuatan minyak klentik telah dilakukan oleh tim Fiabikom Unika Atma Jaya. Untuk melihat proses dan hasil produk minyak klentik dapat di lihat di Youtube dengan ketik "minyak klentik-Pringsewu". Dengan demaikian maka kegiatan pariwisata dapat berdampak pada peningkatan kesejahteraan masyarakat.

\section{Optimalisasi Kegiatan Berbasis Modal Sosial dan Teknologi Informasi dan Komunikasi}

Di atas telah dijelaskan bahwa pendekatan pariwisata berbasis komunitas sangat erat kaitannya dengan modal sosial. Modal sosial pada dasarnya melkiputi tiga aspek yaitu kepercayaan (trust), jejaring (networking) dan nilai (value). Berdasarkan konsep tersebut maka dapat dikatakan bahwa aktivitas komunitas akan lebih efektif dengan menerapkan tiga aspek utama modal sosial. Pada masa dan pasca pandemi ini sebenarnya merupakan suatu kesempatan yang baik untuk membangun modal sosial yang kuat agar kegiatan pariwisata dapat semakin berkualitas dan berlanjut.

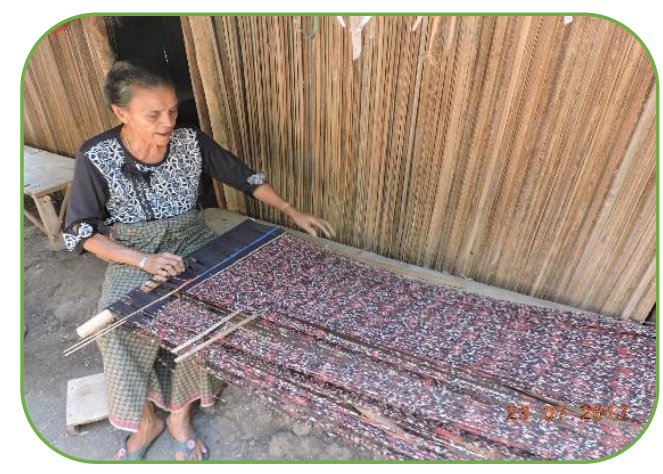

\section{Gambar 1 : Proses Unik Pembuatan Tenun Biboki NTT}

Oleh karena itu dari aspek kepercayaan, komunitas atau pokdarwis harus membangun kepercayaan dengan berbagai mitra dan pemangku kepentingan (pemerintah, pelaku usaha dan komunitas/masyarakat). Beberapa hal yang dapat dilakukan untuk membangun kepercayaan antara lain adanya jaminan keamanan bagi wisatawan, memberikan informasi apa adanya sehingga tidak mengecewakan wisatawan dan pemangku kepentingan lainnya. Dari aspek jejaring pada dasarnya harus melakukan berbagai kerjasama dengan berbagai komunitas, saling mengisi dan mendukung. Dari aspek nilai (value), pada dasarnya harus membangun sebuah keyakinan kepada semua pemangku kepentingan bahwa aktivitas yang dilakukan dapat memberikan manfaat baik bagi seluruh pemangku kepentingan termasuk wisatawan. Pada dasarnya ketiga aspek modal sosial tersebut merupakan satu kesatuan yang tak terpisahkan. Satu dengan yang lain saling melengkapi dan memperkuat. Sebagai contoh seperti yang dilakukan 
oleh ibu almarhumah Yovita Meta dalam mengembangkan wisata tenun biboki di Kefamenanu, NTT (Gambar 1). Beliau membangun jejaring dengan berbagai komunitas khususnya kaum perempuan baik di dalam maupun luar negeri. Gambar 1 di atas merupakan salah satu contoh cara untuk memperkenalkan keunikan proses dan produk tenun Biboki. Selain itu juga dengan pelayanan yang prima (hospitality) kepada setiap wisatawan yang datang menjadi salah satu kunci keberhasilan dalam memasarkan pariwisata tenun dan destinasi pariwisata Biboki NTT. Wisatawan yang berkunjung diajak langsung ketemu dengan para perajin tenun. Demikian juga ketika tim Unika Atma Jaya datang berkunjung ke Kefamenanu oleh ibu Meta kami diantar sendiri ketika berkunjung ke komunitas pengrajin yang menjadi mitranya (naskah dipublikasikan pada Prosiding Comicos UAJY 2018, hal 485).

Pada masa dan pasca pandemi ini pemanfaatan teknologi informasi dan komunikasi (TIK) sangat mendukung terciptanya peningkatan jejaring secara online misalnya yang paling gampang melalui aplikasi wa (grup), facebook (FB), istagram (IG), zoom, youtube dan sebaginya. Seperti dikatakan Poerwanto, dkk. (2021, 243-244) bahwa pada dasarnya kemajuan TIK mampu mengubah perilaku masyarakat baik dalam aspek sosial, buadaya dan perilaku berbisnis. Demikian juga dalam konteks pengembangan destinasi pariwisata, TIK berpengaruh terhadap aktivitas terutama jasa dan pemasaran pariwisata. Teknologi ini sangat membantu karena jangkauannya yang luas, cepat, mudah dan relatif murah. Namun demikian dalam prakteknya perlu mempertimbangkan hal-hal yang cenderung bersifat negatif agar pemanfaatan TIK betukbetul dapat efektif. Seperti dikatakan Poerwanto, dkk,. $(2021,243)$ bahwa “... kemajuan TIK mampu mrngubah perilaku masyarakt tidak hanya menjadi lebih informatif, konsumtif, kreatif, tetapi juga demonstratif dan individualis". Pendapat di atas pada dasarnya menggambarkan pentingnya perilaku bijak dalam bermedia.

Penggunaan TIK yang efektif mampu meningkatkan kinerja industry pariwisata (Poerwanto, dkk., 2021: 251). Selanjutnya dikatakan bahwa terjadi perubahan perilaku masyarakat dalam berwisata. Semula (sebelum pandemi) cenderung bersifat masal, sekarang berubah lebih bersifat khusus atau kelompok kecil (komunitas). Oleh karena itu diperlukan model komunikasi

yang lebih khusus, disesuaikan dengan kebutuhan wisatawan. Sebagai contoh, ada kecenderungan sebagian masyarakat menyukai "selfie". Oleh karena itu perlu disediakan tempattempat untuk selfie yang menarik disesuaikan dengan sasaran pasar (wisatawan-misal untuk anak-anak, remaja, keluarga dll). Ketika foto selfie diunggah ke medeia sosial maka secara tidak langsung dapat memberikan keuntungan bagi semua pihak (pemangku kepentingan). Gambar 2 di bawah adalah foto destinasi Talang Indah yang dapat dan sering dipergunakan untuk foto "selfie" oleh pengunjung. Talang Indah merupakan salah satu destinasi unggulan di kabupaten Pringsewu Lampung.

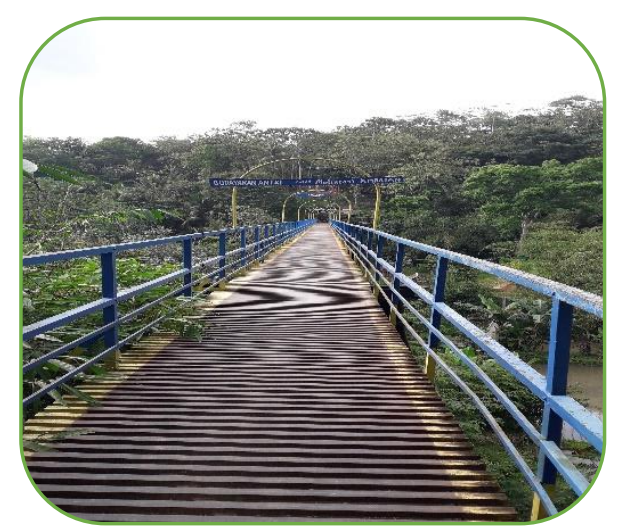

Gambar 2 : Talang Indah Pringsewu Lampung (dokumentasi Tim Peneliti UAJ 2020) 


\section{KESIMPULAN DAN SARAN}

Berdasarkan uraian terkait dengan beberapa konsep seperti pariwisata berkelanjutan, ekowisata, pariwisata berbasis komunitas (CBT) dan modal sosial dan strategi dalam pengelolaan destinasi di masa pasca pandemi di atas maka dapat di simpulkan sebagai berikut :

1. Diperlukan upaya-upaya dengan inovasi kreatif terus menerus untuk menggali, menggunakan dan menjaga berbagai potensi pariwisata di suatu wilayah (destinasi).

2. Terkait dengan penerapan konsep CBT dan Modal Sosial (Trust, Social networking, Value ) maka perlu peningkatan peranserta (partisipasi) masyarakat lokal agar berdampak pada peningkatan ekonomi masyakat (lokal).

3. Pemanfaatan teknologi informasi dan komunikasi (TIK) yang efektif mampu meningkatkan kinerja pengelolaan destinasi pariwisata.

4. Hal yang tidak kalah pentingnya adalah aspek keramahan (hospitality) atau pelayanan yang prima menjadi salah satu faktor keberhasilan dalam memberikan kepuasan kepada wisatawan atau mitra.

5. Hasil penelitian ini pada dasarnya secara teoritis memberikan wawasan pentingnya pengembangan konsep CBT dan Modal Sosial dalam pengelolaan destinasi pariwisata. Secara praktis, penerapan konsep CBT dan Modal Sosial dalam masa pasca pandemi lebih tepat sasaran dengan meningkatkan saling peduli, partisipasi, gotong royong (kemitraan) sehingga peran masyarakat lokal menjadi lebih nyata.

\section{Ucapan Terima Kasih (Acknowledgement)}

Atas terselesaikannya naskah ini kami mengucapkan terima kasih kepada pimpinan Unika Atmajaya yang telah memberikan dukungan dana dan berbagai sarana pendukungnya. Juga kepada Ibu Jovita Meta (Kefamenanu NTT-almarhumah), Bang Rusli (Pulau Untung Jawa) bapak Jahron dan staf Disporapar Kabupaten Pringsewu, Forkom Pokdarwis Kabupaten Pringsewu atas kerjasama dan dukungannya yang sangat baik. Selain itu juga semua pihak yang tidak bisa disebutkan satu per satu dalam tulisan ini. Akhirnya sekecil apapun semoga tulisan ini dapat memberikan manfaat bagi pembacanya.

\section{REFERENSI}

Damanik, Janianton. (2021). ed. Pariwisata Indonesia Kontemporer, Yogyakarta, Penerbit Universitas Gadjah Mada.

Daryanto dan Suprihatin, Agung. (2013). Pengantar Pendidikan Lingkungan Hidup, Yogyakarta, Penerbit Gava Media.

Field, John. (terj. 2018). Modal Sosial, Bantul, Yogyakarta, Penerbit Kreasi Wacana.

Hasbullah, Jousairi. (2006). Social Capital (Menuju Keunggulan Budaya Manusia Indonesia), Jakarta, Penerbit MR-United Press.

Keraf, A. Sonny. (2010). Etika Lingkungan Hidup, Jakarta, Penerbit Kompas.

Marsono. (2019). Agro dan Desa Wisata, Profil Desa Wisata di Daerah Istimewa Yogyakarta dan Jawa Tengah, Yogyakarta, Penerbit Universitas Gadjah Mada.

Muljadi, A.J. (2009). Kepariwisataan dan Perjalanan, Jakarta, Rajawali Press

Nugroho, Iwan. (2019). Ekowisata dan Pembangunan Berkelanjutan, Yogyakarta, Penerbit Pustaka Pelajar.

Poerwanto, dkk., (2021). Tourism Creativity Communication and Transformation, Yogyakarta, Penerbit Pustaka Pelajar.

Prasiasa, Dewa Putu Oka. (2013). Destinasi Pariwisata Berbsis Masyarakat, Jakarta, Penerbit Salemba Humanika.

Siswono, Eko. (2019). Ekologi Sosial, Yogyakarta, Penerbit Ombak. 
Spillane, James J. (1989). Ekonomi Pariwisata, sejarah dan prospeknya, Yogyakarta, Penerbit Kanisius.

Suharsono (2014). "Laporan Konferensi Kemiskinan dan Pemberdayaan Indonesia IPEC (Indonesia Poverty Empowerment Conference)", Munduk Bali tanggal 14-17 Nopember 2014. Tidak dipublikasikan.

Suharsono, Agung Nugroho. (2018). "Peran Komunikasi Interpersonal dalam Pengembangan Kewirausahaan Sosial dan Upaya Peningkatan Kunjungan Wisatawan ke Daerah Tujuan Wisata Berbasis Komunitas (Studi kasus pada komunitas perajin tenun di Biboki, Kefamenanu, NTT)", Naskah hasil penelitian dipublikasikan dalan Prosiding Comicos UAJ Yogyakarta tahun 2018, ISBN No. 978.602.50218-1-7, hal 485.

Suharsono, Heru Prasadja. (2020). "Pemberdayaan Perempuan Melalui Usaha Warung Kopi Tubruk di Pulau Untung Jawa Kepulauan Seribu", Naskah hasil penelitian dan pengabdian dipublikasikan dalam Prosiding Senapenmas 2020 di Untar, hal 990.

Sunaryo, Bambang. (2013). Kebijakan Pembangunan Destinasi Pariwisata, Konsep dan Aplikasinya di Indonesia, Yogyakarta, Penerbit Gava Media.

Suyitno. (2001). Perencanaan Wisata, Yogyakarta, Kanisius.

Undang-undang No, 10 tahun 2009 tentang Kepariwisataan.

Usman, Sunyoto. (2018). Modal Sosial, Yogyakarta, Penerbit Pelajar. 